\title{
Recovery of Metals from Secondary Raw Materials by Coupled Electroleaching and Electrodeposition in Aqueous or Ionic Liquid Media
}

\author{
Nathalie Leclerc ${ }^{1,2}$, Sophie Legeai ${ }^{1,2}$, Maxime Balva ${ }^{1}$ (D) ${ }^{\text {, Claire Hazotte }}{ }^{3}$, Julien Comel ${ }^{1}$, \\ François Lapicque 2,3 , Emmanuel Billy ${ }^{2,4}$ (D) and Eric Meux 1,2,* \\ 1 Groupe Chimie et Electrochimie des Matériaux, Institut Jean Lamour, CNRS-Université de Lorraine, \\ 1 Boulevard Arago, BP 95823, 57078 Metz CEDEX 3, France; nathalie.leclerc@univ-lorraine.fr (N.L.); \\ sophie.legeai@univ-lorraine.fr (S.L.); maxime.balva@univ-lorraine.fr (M.B.); \\ julien.comel@univ-lorraine.fr (J.C.) \\ 2 French Network of Hydrometallurgy Promethée, GDR CNRS 3749, 2 rue du Doyen Roubault, \\ 54518 Vandoeuvre-lès-Nancy, France; francois.lapicque@univ-lorraine.fr (F.L.); \\ EMMANUEL.BILLY@cea.fr (E.B.) \\ 3 Laboratoire Réactions et Génie des Procédés-CNRS-Université de Lorraine ENSIC-1 rue Grandville, \\ 54001 Nancy, France; Claire.Hazotte@econick.fr \\ 4 Laboratoire d'Innovation pour les Technologies des Energies nouvelles et les Nanomatériaux, \\ Université de Grenoble-Alpes_CEA, 38054 Grenoble, France \\ * Correspondence: eric.meux@univ-lorraine.fr
}

Received: 15 June 2018; Accepted: 17 July 2018; Published: 20 July 2018

\begin{abstract}
This paper presents recent views on a hybrid process for beneficiation of secondary raw materials by combined electroleaching of targeted metals and electrodeposition. On the basis of several case studies with aqueous solutions or in ionic liquid media, the paper describes the potential and the limits of the novel, hybrid technique, together with the methodology employed, combining determination of speciation, physical chemistry, electrochemistry, and chemical engineering. On one hand, the case of electroleaching/electrodeposition (E/E) process in aqueous media, although often investigated at the bench scale, appears nevertheless relatively mature, because of the developed methodology, and the appreciable current density allowed, and so it can be used to successfully treat electrode materials of spent $\mathrm{Zn} / \mathrm{MnO}_{2}$ batteries or $\mathrm{Ni} / \mathrm{Cd}$ accumulators and Waelz oxide. On the other hand, the use of ionic liquids as promising media for the recovery of various metals can be considered for other types of wastes, as shown here for the case of electrodes of aged fuel cells. The combined (E/E) technique could be successfully used for the above waste, in particular by the tricky selection of ionic liquid media. Nevertheless, further investigations in physical chemistry and chemical engineering appear necessary for possible developments of larger-scale processes for the recovery of these strategic resources.
\end{abstract}

Keywords: metal recovery; electroleaching; electrodeposition; secondary raw materials; ionic liquids

\section{Introduction}

Leaching can be considered to be the key step for most hydrometallurgical processes. This unit operation is classically performed by chemical reactions on the targeted species using various reagents exhibiting either acid-base properties (e.g., leaching of bauxites by soda in the Bayer Process, leaching of ilmenite $\mathrm{FeTiO}_{3}$ with concentrated $\mathrm{H}_{2} \mathrm{SO}_{4}$ for $\mathrm{TiO}_{2}$ production), or chelating properties as in the cyanidation of gold ores, or oxidative or reductive properties, as for the oxidation of metal sulfides with $\mathrm{Fe}^{3+}$, or the reduction of $\mathrm{MnO}_{2}$ with glucose. 
To improve its effectiveness, chemical leaching can be performed in an autoclave or can be assisted by the means of ultrasound. In addition to chemical leaching, two other techniques can be considered for ore treatment, namely (i) bioleaching (or bio-oxidation), in which bacteria or fungi are employed to extract metal species; (ii) electroleaching, for which oxidative/reductive reagents are replaced by electrons in electrochemical reactions. Electroleaching is considered to be "direct" when compounds react at the electrodes or "indirect" —or assisted—in case where chemical reagents are generated at the electrodes to perform leaching: an example is the action of anodically generated chlorine from the chloride-based electrolyte.

The first studies dealing with electroleaching in extractive metallurgy were devoted to the treatment of sulfides ores [1]. Due to their good electrical conductivity, metal sulfides were treated by direct electroleaching using consumable anodes formed by the sulfide to be converted, or blended with graphite to improve the conductivity of the formed anodes. Various sulfides have been investigated: chalcocite $\mathrm{Cu}_{2} \mathrm{~S}$, chalcopyrite $\mathrm{CuFeS}_{2}$, galena $\mathrm{PbS}$, and sphalerite $\mathrm{ZnS}$. For a divalent sulfide, the anodic dissolution can be written as follows:

$$
\mathrm{MS}_{(\mathrm{s})} \rightarrow \mathrm{M}^{2+}+\mathrm{S}_{(\mathrm{s})}+2 \mathrm{e}^{-}
$$

For the above-mentioned treatments reported in the literature, a simultaneous cathodic deposition occurred.

Kirk et al. [2] investigated the electrochemical leaching of silver arsenopyrite. However, in this case, electroleaching was indirect and consisted of the anodic generation of chlorine gas from hydrochloric acid. Although less encountered, reductive electroleaching of ores can also be considered, as shown by a couple of published papers. This reductive electroleaching, mainly direct, was performed with natural resources containing $\mathrm{MnO}_{2}$-in which the manganese cation was cathodically dissolved from the oxide present in the low-grade manganese ores [3], or in polymetallic ocean nodules [4]. Apart from the beneficiation of mineral ores, electroleaching can be applied to the treatment of secondary raw materials, in particular, that of printed circuit boards, either by direct electro-dissolution [5,6] or by generation of an oxidizing reagent at the anode [7].

In hydrometallurgical processes, the metals of interest in the form of single or complexed ions are recovered by electrowinning. Therefore, it is possible to imagine hybrid processes where, in a single cell, metals-under various chemical forms-are leached (directly or not) at the anode, the metal ions produced will migrate to the cathode in the same cell, where they are reduced to form the metal deposit. This combined technique is presented more in detail below:

- Coupling electro-assisted leaching to electrodeposition

The principle is described in Figure 1a. The material to be treated is placed in the anodic compartment of the cell. The leaching reagent is produced at the anode $\left(\mathrm{H}^{+}, \mathrm{Cl}_{2}, \mathrm{Fe}^{3+} \ldots\right)$. These compounds allow the occurrence of the dissolution of metal species present in the solid-liquid matrix (pulp) under various mineralogical forms e.g., metal, oxides or sulfides. The metal cations formed migrate to the cathode where the reduction can be selective or not. A separator is generally placed between the anode and cathode to prevent the attrition of the metal deposit by the solid particles.

- Coupling direct electroleaching to electrodeposition

The principle is presented in Figure 1b. In this case, the anode is formed by the material to be leached, alone, if its conductivity is sufficient, or mixed with fine carbon powder for enhanced electrical conductivity of the anode. 


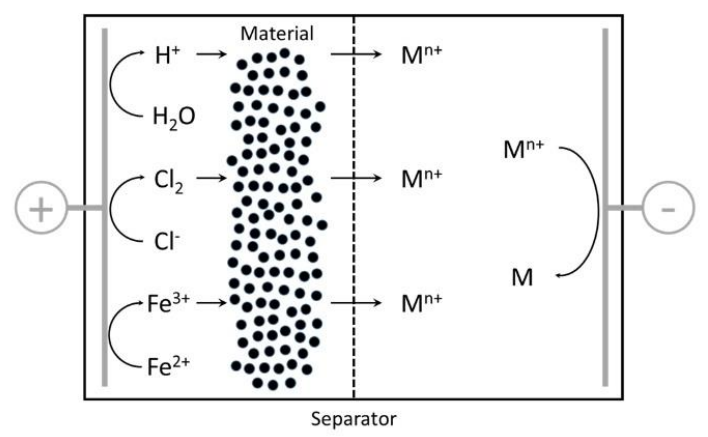

(a)

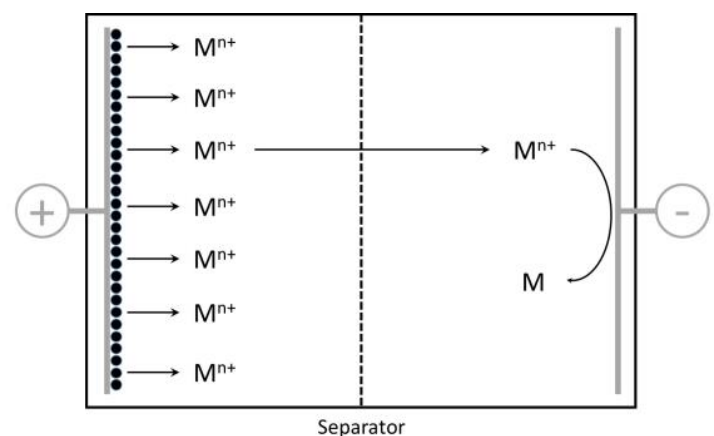

(b)

Figure 1. Scheme of the coupled electro-assisted leaching electrodeposition (a) and direct electroleaching/electrodeposition (b) conducted in a single-cell.

Most studies devoted to coupling electroleaching to electrodeposition in a single-cell have been carried out in aqueous media e.g., $\mathrm{H}_{2} \mathrm{SO}_{4}$ or $\mathrm{HCl}$ solutions, with or without metal salts. The use of non-aqueous media such as ionic liquids (ILs) usually exhibiting broad electrochemical windows, could allow extension of the process to the case of noble metals $(\mathrm{Pt}, \mathrm{Pd}, \mathrm{Rh} \ldots)$ and to the recovery of metal elements such as rare-earths or tantalum, which is not possible in water-based liquids $[8,9]$.

Examples of electroleaching/electroreduction processes at bench scale are presented in Table 1.

Table 1. Typical examples of coupled electroleaching/electrodeposition in a single-cell.

\begin{tabular}{|c|c|c|c|c|c|c|c|}
\hline Materials & Electroleaching & $\begin{array}{c}\text { Number of } \\
\text { Compartments }\end{array}$ & $\begin{array}{l}\text { Anode with } \\
\text { (Reaction) }\end{array}$ & $\begin{array}{l}\text { Cathode with } \\
\text { (Reaction) }\end{array}$ & Electrolyte & Separator & Ref. \\
\hline $\begin{array}{l}\mathrm{Fe} / \mathrm{Ni} \text { sulfides } \\
\text { concentrates }\end{array}$ & Assisted & 2 & $\begin{array}{c}\text { Graphite } \\
\left(\mathrm{Cl}_{2} \text { generated by }\right. \\
\left.\text { oxidation of } \mathrm{Cl}^{-}\right)\end{array}$ & $\begin{array}{c}\text { Titanium } \\
\text { (Ni deposition) }\end{array}$ & $\begin{array}{c}\text { Anolyte: } \mathrm{NaCl} / \mathrm{HCl} \\
\text { Catholyte: } \mathrm{NaCl} / \mathrm{HBO}_{2}\end{array}$ & $\begin{array}{c}\text { Cation } \\
\text { Exchange Membrane }\end{array}$ & [10] \\
\hline $\begin{array}{c}\mathrm{ZnO} \\
\text { dispersed in } \\
\text { a sand matrix }\end{array}$ & Assisted & 3 & $\begin{array}{l}\text { Lead }\left(\mathrm{H}^{+} \text {generated }\right. \\
\text { by oxidation of } \\
\text { water })\end{array}$ & $\begin{array}{l}\text { Stainless steel } \\
\text { (Zn deposition) }\end{array}$ & $\begin{array}{c}\text { Anolyte: } \mathrm{H}_{2} \mathrm{SO}_{4} \\
\text { Catholyte: } \mathrm{H}_{2} \mathrm{SO}_{4} / \mathrm{ZnSO}_{4}\end{array}$ & Polypropylene cloth & [11] \\
\hline PCB powder & Direct & 1 & Stainless steel basket & $\begin{array}{l}\text { Stainless steel } \\
\text { (Cu deposition) }\end{array}$ & $\mathrm{H}_{2} \mathrm{SO}_{4} / \mathrm{CuSO}_{4}$ & - & [12] \\
\hline $\begin{array}{l}\mathrm{Ni} / \mathrm{Cd} \text { spent } \\
\text { batteries }\end{array}$ & Assisted & 2 & $\begin{array}{l}\text { Platinized titanium } \\
\left(\mathrm{H}^{+} \text {generated by }\right. \\
\text { oxidation of water })\end{array}$ & $\begin{array}{c}\text { Aluminium } \\
\text { (Cd deposition) }\end{array}$ & $\begin{array}{l}\text { Anolyte: diluted } \mathrm{H}_{2} \mathrm{SO}_{4} \\
\text { Catholyte: } \mathrm{H}_{2} \mathrm{SO}_{4} / \mathrm{CdSO}_{4}\end{array}$ & Polypropylene cloth & [13] \\
\hline $\begin{array}{l}\text { Membrane } \\
\text { Electrode } \\
\text { Assembly of } \\
\text { spent PEMFC }\end{array}$ & Direct & 1 & Spent MEA & $\begin{array}{c}\text { Graphite } \\
\text { (Pt deposition) }\end{array}$ & $\begin{array}{c}\text { Ionic liquid mixtures } \\
{[\mathrm{BMIm}] \mathrm{Cl}^{1}} \\
{\left[\mathrm{BMIm}^{\mathrm{T} F S I^{2}}\right.}\end{array}$ & - & [14] \\
\hline $\mathrm{Ag}_{2} \mathrm{~S} / \mathrm{Ag}$ & Direct & 1 & $\begin{array}{l}\text { Carbon Paste } \\
\text { Electrode with } \\
\mathrm{Ag}_{2} \mathrm{~S} / \mathrm{Ag}\end{array}$ & $\begin{array}{c}\text { Graphite } \\
\text { (Ag deposition) }\end{array}$ & $\begin{array}{l}\mathrm{Na}_{2} \mathrm{~S}_{2} \mathrm{O}_{3} \\
\mathrm{Na}_{2} \mathrm{SO}_{3}\end{array}$ & - & [15] \\
\hline
\end{tabular}

BMIm = 1-butyl, 3-methylimidazolium; TFSI = bis(trifluorosulfonyl)imide.

This paper is aimed at presenting the potential of metal recovery from secondary raw materials by coupled electroleaching electrodeposition on the basis of the systems shown in Table 1: in spite of the differences in the examples and beyond the performance attained, efforts have been put here on methodological aspects to be accounted for in the design of such processes, namely comparison of the importance of reaction and transfer phenomena, together with the significance of complexation allowed by the solvents, in particular with ionic liquids. The paper is divided into two parts. First, we present coupled electroassisted leaching electroreduction in an aqueous medium for the case of zinc-containing waste issued by steel manufacturing plants [11] and he "black mass" contained in nickel/cadmium spent batteries [13]. In this part, investigation of the various physicochemical phenomena (chemical reaction, transport, electrochemical processes) involved allowed better understanding of the overall process, for possible design and estimation of capacities and limits of the technique. Secondly, the coupled direct electroleaching electrodeposition in ionic liquids has been developed for spent membrane electrode assemblies (MEA) of proton exchange membrane fuel cells (PEMFC) [14], for the 
recovery of $\mathrm{Pt}$ from the electrodes. The works described in this second part are more recent, and the use of ILs for electroleaching/electroreduction is still poorly described in the relevant literature. In this part, emphasis is put more significantly on the physicochemical aspects of Pt species to be dissolved in ionic liquids, which had to exhibit high complexing properties while allowing Pt deposition at the cell cathode.

\section{Electro-Assisted Leaching/Electroreduction in Aqueous Media}

\subsection{Principle}

The principle of electro-assisted leaching/electrodeposition studied here consists of the generation of protons by electrochemical oxidation of water according to:

$$
2 \mathrm{H}_{2} \mathrm{O} \rightarrow 4 \mathrm{H}^{+}+\mathrm{O}_{2(\mathrm{~g})}+4 \mathrm{e}^{-}
$$

Protons produced by reaction (2) can react with metals, metal hydroxides, or metal oxides. Then, $\mathrm{M}^{z+}$ cations released, move towards the cathode compartment where they are reduced, selectively or not, with a current efficiency depending on the reversible potential of $\mathrm{M}^{z+} / \mathrm{M}$ couple and taking into account the possible occurrence of water electro-reduction according to:

$$
2 \mathrm{H}_{2} \mathrm{O}+2 \mathrm{e}^{-} \rightarrow 2 \mathrm{OH}^{-}+\mathrm{H}_{2(\mathrm{~g})}
$$

\subsection{Experimental Section and Methodology}

\subsubsection{Design of the Cell}

Tests of electro-assisted leaching coupled to electrodeposition were carried out in a laboratory-made cell [11], made of PVC and consisting of compartments-of a variable number. Figure 2 shows a two-compartment cell. Its detailed description has been presented in previous papers with different configurations in the treatment of zinc-containing waste [16], or black mass from nickel/cadmium spent batteries [17]. In all cases, the cell was assembled with PVC elements (9 $\mathrm{cm}$ high and $7 \mathrm{~cm}$ wide and with an adjustable depth). Fluid circulation in each compartment was made possible by inlet and outlet tubes: one on the top of one side and a second at the bottom of the other side. A peristaltic pump was used for circulation of the liquids at a flow rate fixed at $0.9 \mathrm{~L}$ $\min ^{-1}$. The cell-operated batchwise-was not covered by a lid for sampling of the solution, addition, or extraction of the solid waste along the runs, stirring of the solid waste, and monitoring of variables such as $\mathrm{pH}$ and potential, and finally for the evacuation of evolved gases e.g., $\mathrm{H}_{2}$. Each compartment was separated from the others by a polypropylene (PP) cloth.

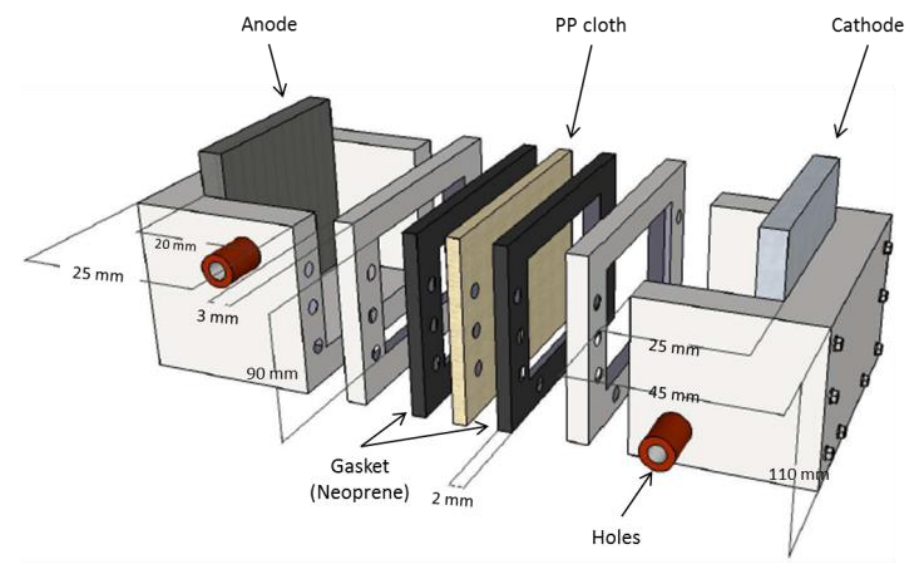

Figure 2. Laboratory-made cell for electro-assisted leaching and electrodeposition in aqueous media. 


\subsubsection{Solid Waste}

Various solids have been investigated in the above cell in the form of ground particles, as follows:

- $\quad$ Synthetic Zn-containing waste: this synthetic solid was prepared by dispersing $10 \mathrm{wt}$. \% zinc oxide $\mathrm{ZnO}$ in sand.

- $\quad$ Reconstructed black mass from spent $\mathrm{Ni} / \mathrm{Cd}$ batteries: the active powders from spent $\mathrm{Ni} / \mathrm{Cd}$ batteries (so-called "black mass") were used. Black mass was recovered from end-of-life SANYO batteries after manual dismantling [18]. The active powders of anode and cathode were gathered and homogenized to give a reconstructed black mass. This material has the following composition: 51 wt. \% Cd(OH $)_{2}, 30$ wt. \% Ni(OH) 2,13 wt. \% Ni, approx. 1 wt. \% NiOOH and about 2.5 wt. \% $\mathrm{Co}(\mathrm{OH})_{2}$.

- Waelz oxide was produced by carbothermal reduction of electric arc furnace dust (EAFD). The sample studied was provided by Recytech S.A (Fouquières-lès-Lens, France). In this sample, zinc was present in different forms: $90 \% \mathrm{ZnO}, 8 \% \mathrm{Zn}$ and $2 \% \mathrm{ZnFe}_{2} \mathrm{O}_{4}$ )

- $\quad$ Black mass from spent $\mathrm{Zn} / \mathrm{MnO}_{2}$ batteries. A sample of industrial black mass was provided by Eurodieuze Industrie (Dieuze, France). This material was obtained after the different mechanical stages as follows: crushing of spent batteries, magnetic sorting to recover steel chips, Eddy current sorting to recover non-ferrous metals, and removal of plastics and papers by air entrainment. Zinc and manganese form distributions were as follows: zinc (47.3\% $\mathrm{ZnO}$ and $52.7 \% \mathrm{Zn})$, and manganese (35.4\% $\mathrm{MnOOH}$ and $64.6 \% \mathrm{MnO}_{2}$ ).

- Industrial black mass from spent $\mathrm{Ni} / \mathrm{Cd}$ batteries. This sample was also provided by Eurodieuze Industrie (Dieuze, France). Its composition is given in Table 2 [19]. The main difference with reconstructed black mass is the presence of small amounts of carbon and $\mathrm{Fe} / \mathrm{Fe}(\mathrm{OH})_{3}$, resulting from incomplete magnetic sorting.

The three black mass solids investigated consisted of coarse particles, with an average diameter near $1 \mathrm{~mm}$, whereas the particles of zinc-containing solids were somewhat finer, with an average diameter in the order of $200 \mu \mathrm{m}$.

Table 2. Composition of industrial black mass coming from spent Ni/Cd batteries [19].

\begin{tabular}{|c|c|c|c|c|c|c|c|c|c|}
\hline Black Mass & $\mathrm{Ni}(\mathrm{OH})_{2}$ & $\mathrm{Ni}$ & $\mathrm{Cd}(\mathrm{OH})_{2}$ & $\mathrm{Cd}$ & $\mathrm{Co}(\mathrm{OH})_{2}$ & Co & $\mathrm{Fe}(\mathrm{OH})_{3}$ & $\mathrm{Fe}$ & $\mathrm{C}$ \\
\hline Composition (wt. \%) & 28.7 & 20.2 & 37.2 & 3.3 & 1.6 & 0.3 & 1.0 & 0.6 & 2.0 \\
\hline
\end{tabular}

\subsubsection{Experiments}

As a first step and for each waste, leaching and electrodeposition have been separately investigated in conventional laboratory cells. These preliminary investigations aimed at determining the leaching kinetics of the waste components and the optimum current density for obtaining a compact, regular metal deposit.

Then, these two steps were achieved in the cell shown in Figure 2 with various configurations, in particular with two or three compartments, with or without fluid circulation and with or without stirring of the solid-liquid suspension, in order to follow the time variations of the concentrations of the various species. For investigation of electro-assisted leaching without electrodeposition of the leached species, an anionic-supported membrane (Eurodia) was installed to replace the PP cloth, which separated the cathodic compartment from the central chamber containing the suspension [11,20].

Tests of combined electroleaching-electrodeposition were aimed to define the best electrolytes compositions and the optimal operating conditions (current density, influence of fluid circulation, and waste stirring) for the highest performance of the cell, in terms of leaching and deposition efficiencies, quality of the metal product, and purity of the solution recovered at the end of the runs. 
- Configuration of the cell for zinc electroleaching/electrodeposition

A three-compartment cell was used (Figure 3). Synthetic waste was introduced in the central chamber ( $2.5 \mathrm{~cm}$ thick) separated from anodic and cathodic compartments by polypropylene clothes (Sefar Fyltis).

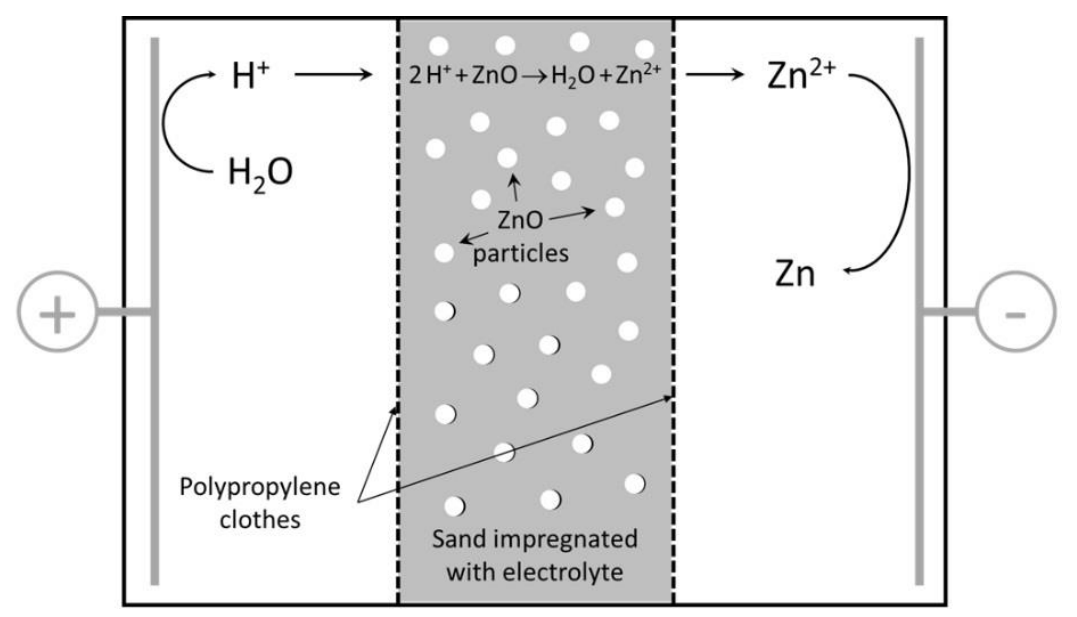

Figure 3. Cell configuration for electro-assisted leaching/electrodeposition applied to $\mathrm{ZnO} /$ sand mixture.

A lead plate anode was inserted in the cell, whereas the cathode was either a stainless steel or an aluminum plate. Both electrodes had the same active area, at $53 \mathrm{~cm}^{2}$. The anolyte was a diluted $\mathrm{H}_{2} \mathrm{SO}_{4}$ solution to ensure a sufficient electrical conductivity and to minimize the ohmic drop in the early stages of the experiment. For the same reason, $\mathrm{ZnO} /$ sand solid was impregnated by diluted $\mathrm{H}_{2} \mathrm{SO}_{4}$. The catholyte was a mixed $\mathrm{H}_{2} \mathrm{SO}_{4}, \mathrm{ZnSO}_{4}$ solution.

- Configuration of the cell for $\mathrm{Ni} / \mathrm{Cd}$ electroleaching/electrodeposition

A two-compartment cell was used (Figure 4) with a platinized titanium anode for $\mathrm{O}_{2}$ and $\mathrm{H}^{+}$ generation, and an aluminum cathode (active area near $53 \mathrm{~cm}^{2}$ ). Black mass was directly added to the anodic compartment with diluted $\mathrm{H}_{2} \mathrm{SO}_{4}$ as the anolyte solution. Catholyte was a mixed $\mathrm{H}_{2} \mathrm{SO}_{4} / \mathrm{CdSO}_{4}$ solution. A PP cloth (Mortelecque, France) separated the two compartments.

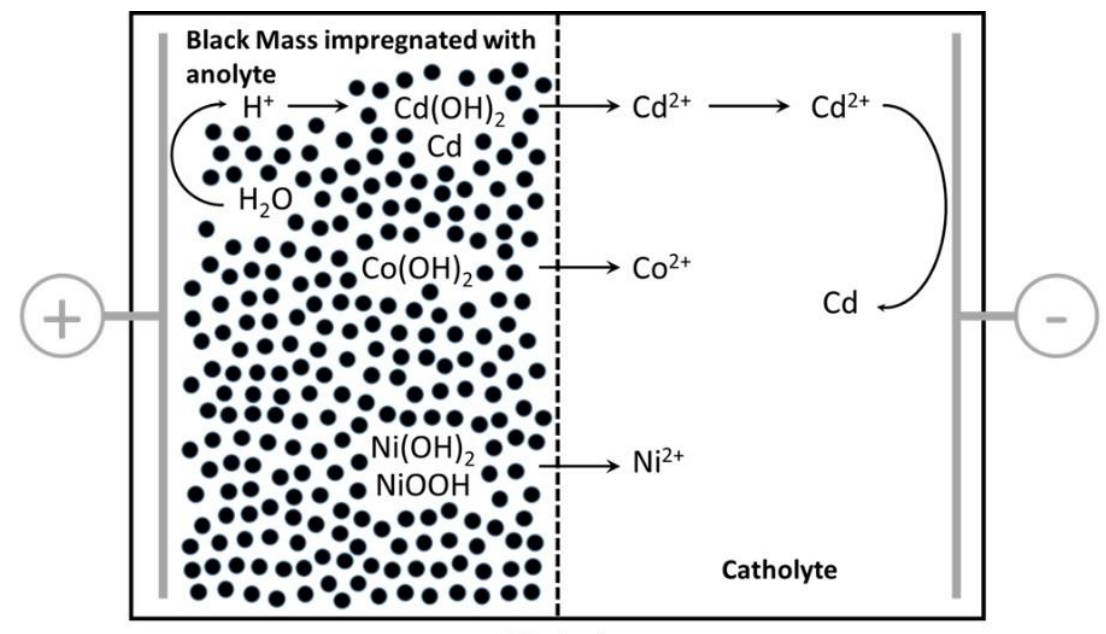

PP cloth

Figure 4. Cell configuration for electroleaching/electrodeposition applied to Ni/Cd Black Mass. 
In comparison with the $\mathrm{ZnO} /$ sand blend, leaching reactions were more complex. Electro-generated protons were consumed in:

- Acidic dissolution of metal hydroxides after:

$$
\mathrm{M}(\mathrm{OH})_{2}+2 \mathrm{H}^{+} \rightarrow \mathrm{M}^{2+}+2 \mathrm{H}_{2} \mathrm{O}^{+}
$$

- Oxidation of metal cadmium:

$$
\mathrm{Cd}+2 \mathrm{H}^{+} \rightarrow \mathrm{Cd}^{2+}+\mathrm{H}_{2(\mathrm{~g})}
$$

- Reduction of $\mathrm{NiOOH}$ :

$$
4 \mathrm{NiOOH}+8 \mathrm{H}^{+} \rightarrow 4 \mathrm{Ni}^{2+}+6 \mathrm{H}_{2} \mathrm{O}+\mathrm{O}_{2(\mathrm{~g})}
$$

The three industrial samples were investigated with the cell configuration shown in Figure 4.

\subsection{Results and Discussion}

\subsubsection{Synthetic Zinc-Containing Waste}

The study of optimal conditions of zinc electrowinning [21] had shown that operating at a current density of $450 \mathrm{~A} \cdot \mathrm{m}^{-2}$ allowed formation of a compact zinc deposit. The best electrolyte compositions for combined electro-assisted leaching and electrodeposition treatment were found to be as follows [11]: (i) $125 \mathrm{~mL}$ of $\mathrm{H}_{2} \mathrm{SO}_{4} 0.01 \mathrm{M}$ introduced in the cathode chamber; (ii) the central (waste) compartment filled with $100 \mathrm{~mL}$ of $0.01 \mathrm{M} \mathrm{H}_{2} \mathrm{SO}_{4}, 0.5 \mathrm{M} \mathrm{ZnSO}_{4}$ in the presence of $133 \mathrm{~g} \mathrm{ZnO}$-sand mixture; (iii) the catholyte was $125 \mathrm{~mL} 0.5 \mathrm{M} \mathrm{H}_{2} \mathrm{SO}_{4} 0.5 \mathrm{M} \mathrm{ZnSO}_{4}$ medium. This last composition was selected after thorough studies of zinc deposition in a Hull cell with various $\mathrm{Zn}$ sulfate sulfuric solutions [21].

In typical runs, the three-compartment cell was operated for $6 \mathrm{~h}$ at $450 \mathrm{~A} \cdot \mathrm{m}^{-2}: 97 \%$ of the $\mathrm{ZnO}$ introduced was leached, and $75 \%$ of the leached zinc could be recovered in the form of compact metal without dendrites and exhibiting no powdery aspect-this fraction is called here deposition yield, and the deposition current efficiency attained $60 \%$. It was also shown that circulation of electrolytes and stirring of the pulp had a positive influence on leaching and deposition processes, for the latter process in terms of current efficiency and morphology of the deposit produced.

The power consumption for this treatment was estimated at $23.7 \mathrm{kWh} \cdot \mathrm{kg}^{-1}$. Even if this value was in good agreement with the work of Page et al. [10], it was much higher than that required for the only zinc electrodeposition from sulfate/sulfuric medium, near $3.5 \mathrm{kWh} \cdot \mathrm{kg}^{-1}$ [22] or even the free enthalpy difference in a zinc performing $\mathrm{Zn}$ deposition and oxygen evolution under standard conditions, at approx. $1.63 \mathrm{kWh} \cdot \mathrm{kg}^{-1}$. It should be noted that the power consumption involved in the electro-assisted leaching operation was not accounted for in [22] and the above thermodynamic energy estimated relies also a 100\% current efficiency for Zn deposition. Moreover, the design of the cell for these first tests was far from optimal, with presumably significant ohmic drop due to appreciable electrode gap in the laboratory cell, in addition to the electrode overpotentials. Therefore, in order to decrease the power consumption, it was decided that one compartment would be removed to avoid the resistance induced by the cloth, and to reduce the distance between the two electrodes. All tests with industrial wastes were performed with a two-compartment cell.

\subsubsection{Reconstructed Black Mass from Spent $\mathrm{Ni} / \mathrm{Cd}$ Batteries}

The objective of this study was to obtain, on one hand, a solid residue containing only metal nickel and carbon, and on the other hand, metal cadmium of acceptable quality. This study also intended to produce a pure cadmium-free solution of metal salts. A current density of $350 \mathrm{~A} \cdot \mathrm{m}^{-2}$ was shown to correspond to the best conditions for the combined leaching and formation of a compact cadmium deposit at the cathode [20]. 
Optimum electrolyte compositions [13] were as follows. The cathode chamber was filled with a suspension prepared with $170 \mathrm{~mL}$ of $0.05 \mathrm{M} \mathrm{H}_{2} \mathrm{SO}_{4}$, with $20 \mathrm{~g}$ reconstructed black mass, whereas the anolyte was $156 \mathrm{~mL} 0.05 \mathrm{M} \mathrm{H}_{2} \mathrm{SO}_{4}$, and $0.6 \mathrm{M} \mathrm{CdSO}_{4}$. It was also observed that more regular operation was allowed with continuous circulation of the two media in the compartment, with stirring of the suspension in the anodic chamber.

During all experiments, samples were collected regularly in each compartment with a view to monitor the variations of cadmium, nickel, cobalt, and acidic species $\left(\mathrm{H}^{+}\right.$and $\left.\mathrm{HSO}_{4}{ }^{-}\right)$concentrations along time.

After $5 \mathrm{~h}$ treatment, the solid residue, the cathodic deposit, and the electrolytes were submitted to analysis: the results are reported in Table 3.

Table 3. Composition of electrolytes and solids after $5 \mathrm{hr}$ treatment at $350 \mathrm{~A} \cdot \mathrm{m}^{-2}$.

\begin{tabular}{ccccccc}
\hline & $\mathbf{C d}$ & $\mathbf{N i}$ & $\mathbf{C o}$ & $\mathbf{N i}(\mathbf{O H})_{2}$ & $\mathbf{C d}(\mathbf{O H})_{2}$ & $\mathrm{C}$ \\
\hline Catholyte $\left(\mathrm{g} \cdot \mathrm{L}^{-1}\right)$ & 0.3 & 11.2 & 0.9 & & & \\
Anolyte $\left(\mathrm{g} \cdot \mathrm{L}^{-1}\right)$ & 21.4 & 15.9 & 0.9 & - & - & - \\
Deposit $($ wt. \%) & 99.7 & 0.2 & 0.02 & & & \\
Solid residue $($ wt. \%) & 0 & 79 & 0 & 17 & 2 & 2 \\
\hline
\end{tabular}

It can be seen in this Table that the residual solid contained predominantly nickel and that the cadmium deposit was of a high purity (99.7\%). The leaching yield of cadmium was close to $99 \%$. Because of its low cadmium content, the catholyte should be valuable in nickel industry after hydroxide precipitation. The obtained anolyte was a mixed $\mathrm{Ni} \mathrm{Cd}$ solution which could be reused to prepare the catholytic solution for further runs.

As also observed for the treatment of zinc-containing waste, the performance and efficiency of the overall operation was governed by several factors: generation of protons at the anode, dissolution of the particles, transport of metal cations to the cathodic chamber, in particular through the cloth, and electrochemical deposition. As a matter of fact, several phenomena appeared crucial in the overall performance [20]:

- Leaching of solid particles was revealed to be controlled by both mass transfer of protons to the solid surface, and by the rate of surface chemical reaction: use of finer waste particles improved the overall process efficiency.

- Transport of generated metal cations occurs by migration, in addition to possible occurrence of convection and diffusion. The current density is fixed in the chronopotentiometric runs, so metal cations are selectively transported to the cathode if their transference number is high, i.e., if that of protons remains at a low/moderate level: for this reason, the solution $\mathrm{pH}$ has to obey a compromise between sufficient fast leaching of metal oxides or hydroxides and a moderate content of acidic ions.

- Such compromise in acid concentration is also important for the electrodeposition step at the cathode, for the sake of little significant side evolution of hydrogen, and to avoid formation of metal hydroxide at the cathode surface, with local $\mathrm{pH}$ larger than that in the bulk.

- Transport through the PP cloth can be also rate-controlling, in particular with using materials prepared with woven bundles of thin polymeric fibers and exhibiting a low overall permeability.

These conclusions could guide the definition of operating conditions for treatment of industrial wastes, and help in the design of an electroleaching/electrodeposition process.

\subsubsection{Industrial Samples}

The experimental conditions and results obtained in the optimized treatment of the three industrial wastes are summarized in Table 4.

The data reported in Table 4 allowed the following conclusions on the process to be drawn: 
- Waelz oxide. Initially at $5 \mathrm{wt}$. \%, the residual solid was lead-enriched, with a final fraction at $35 \%$ after the run. Lead was in $\mathrm{PbSO}_{4}$ mineralogical form. This solid could be reused in lead metallurgy. Moreover, $99.9 \%$ zinc deposit was produced, for possible reuse in galvanization processes. The final anolyte could be used as a catholyte for further runs, after upgrading by concentration adjustment.

- $\mathrm{Zn}-\mathrm{MnO}_{2}$ spent batteries. The treated solid contained a slight amount of zinc and its manganese concentration was almost increased twofold. Pure zinc was deposited at the cathode, and the electrolytes could be reused for further treatment runs.

- $\mathrm{Ni} / \mathrm{Cd}$ spent batteries. Nickel and cadmium hydroxides were entirely leached. Metal nickel and carbon concentrations in the solid recovered were increased fourfold. This could be of use in nickel metallurgy. The $\mathrm{Cd}$ cathode deposit does not have a large market value but could be dissolved to prepare new electrolytes. The anolyte could be reused as catholyte for further runs or could be of use in nickel metallurgy after precipitation of the hydroxides.

Table 4. Electro-assisted leaching/electrodeposition of various industrials wastes (or byproduct) in the discontinuous process.

\begin{tabular}{|c|c|c|c|c|}
\hline & & Waelz Oxide [11] & $\begin{array}{c}\mathrm{Zn}-\mathrm{MnO}_{2} \text { Spent } \\
\text { Batteries [11] }\end{array}$ & Ni/Cd Spent Batteries [19] \\
\hline \multirow{12}{*}{ 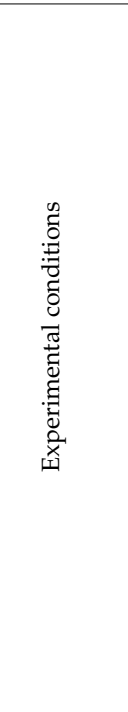 } & $\mathrm{J}\left(\mathrm{A} \cdot \mathrm{m}^{-2}\right)$ & \multicolumn{2}{|c|}{450} & 350 \\
\hline & Run duration (h) & 6 & 8 & 6 \\
\hline & Type of anode & \multicolumn{2}{|c|}{$\mathrm{Pb}$} & Platinized Titanium \\
\hline & Anolyte volume $(\mathrm{mL})$ & 130 & 150 & 170 \\
\hline & Anolyte composition (M) & \multicolumn{2}{|c|}{$\begin{array}{l}\mathrm{H}_{2} \mathrm{SO}_{4}: 0.1 \\
\mathrm{ZnSO}_{4}: 0.2\end{array}$} & $\begin{array}{c}\mathrm{H}_{2} \mathrm{SO}_{4}: 0.1 \\
\text { Addition of } 3 \mathrm{~mL} 2 \mathrm{M} \\
\mathrm{CdSO}_{4} \text { every } 60 \mathrm{~min}\end{array}$ \\
\hline & Type of cathode & \multicolumn{2}{|c|}{$\mathrm{Al}$} & $\mathrm{Al}$ \\
\hline & Catholyte volume (mL) & 125 & 150 & 220 \\
\hline & Catholyte composition (M) & $\begin{array}{l}\mathrm{H}_{2} \mathrm{SO}_{4}: 0.5 \\
\mathrm{ZnSO}_{4}: 0.5\end{array}$ & $\begin{array}{c}\mathrm{H}_{2} \mathrm{SO}_{4}: 0.25 \\
\mathrm{ZnSO}_{4}: 0.5\end{array}$ & $\begin{array}{l}\mathrm{H}_{2} \mathrm{SO}_{4}: 0.5 \\
\mathrm{CdSO}_{4}: 0.49\end{array}$ \\
\hline & Weight of processed solid (g) & 20 & 25 & 30 \\
\hline & Procedure for solid addition & \multicolumn{2}{|c|}{ Initial introduction } & $\begin{array}{l}5 \mathrm{~g} \text { at initial time, then } 5 \mathrm{~g} \\
\text { added every hour }\end{array}$ \\
\hline & $\begin{array}{c}\text { Procedure for extraction } \\
\text { of the residual solid }\end{array}$ & \multirow{2}{*}{\multicolumn{2}{|c|}{ Extraction at the end of the run }} & $\begin{array}{l}\text { Extraction every hour before } \\
\text { addition of solids }\end{array}$ \\
\hline & $\begin{array}{l}\text { Procedure for extraction } \\
\text { of the deposit }\end{array}$ & & & Extraction every hour \\
\hline \multirow{3}{*}{ Yields (\%) } & Leaching yield & Zn: 99.1 & Zn: 96.3 & $\mathrm{Ni}(\mathrm{OH})_{2}$ and $\mathrm{Cd}(\mathrm{OH})_{2}: 100$ \\
\hline & Faradaic yield & 61 & 37 & 52.6 \\
\hline & Deposition yield & 61 & 75.7 & 56.8 \\
\hline \multicolumn{5}{|c|}{ After electro-assisted leaching/electrodeposition } \\
\hline \multicolumn{2}{|c|}{ Residual solid composition (wt. \%) } & $\begin{array}{c}\text { Zn: } 0.3 \\
\mathrm{~Pb}: 34.9 \\
\text { Fe: } 4.7 \\
\text { Si: } 10.6\end{array}$ & $\begin{array}{c}\text { Mn: } 45.2 \\
\text { Zn: } 1.4 \\
\text { Fe: } 1.5\end{array}$ & $\begin{array}{c}\text { Ni: } 82.8 \\
\text { C: } 8.7 \\
\text { Cd: } 1.4 \\
\text { Fe: } 1.1\end{array}$ \\
\hline \multicolumn{2}{|c|}{ Weight of deposit (g) } & 10.7 & 8.6 & 13.4 \\
\hline \multicolumn{2}{|c|}{ Deposit composition (wt. \%) } & $\begin{array}{l}\mathrm{Zn}: 99.9 \\
\mathrm{~Pb}: 0.06\end{array}$ & $\begin{array}{l}\mathrm{Zn:} 99.8 \\
\mathrm{Cu}: 0.09\end{array}$ & $\begin{array}{c}\mathrm{Cd}: 90 \\
\mathrm{Cd}(\mathrm{OH})_{2}: 10\end{array}$ \\
\hline \multicolumn{2}{|c|}{ Anolyte composition (M) } & $\begin{array}{l}\mathrm{H}_{2} \mathrm{SO}_{4}: 0.42 \\
\mathrm{ZnSO}_{4}: 0.36\end{array}$ & $\begin{array}{l}\mathrm{H}_{2} \mathrm{SO}_{4}: 0.6 \\
\mathrm{ZnSO}_{4}: 0.2 \\
\mathrm{MnSO}_{4}: 0.1\end{array}$ & $\begin{array}{l}\mathrm{H}_{2} \mathrm{SO}_{4}: 0.54 \\
\mathrm{NiSO}_{4}: 0.25 \\
\mathrm{CdSO}_{4}: 0.13\end{array}$ \\
\hline \multicolumn{2}{|c|}{ Catholyte composition (M) } & $\begin{array}{l}\mathrm{H}_{2} \mathrm{SO}_{4}: 0.02 \\
\mathrm{ZnSO}_{4}: 0.04\end{array}$ & $\begin{array}{l}\mathrm{H}_{2} \mathrm{SO}_{4}: 0.09 \\
\mathrm{ZnSO}_{4}: 0.02 \\
\mathrm{MnSO}_{4}: 0.1\end{array}$ & $\begin{array}{l}\mathrm{H}_{2} \mathrm{SO}_{4}: 0.7 \\
\mathrm{NiSO}_{4}: 0.21 \\
\mathrm{CdSO}_{4}: 0.02\end{array}$ \\
\hline
\end{tabular}




\section{Direct Electroleaching/Electrodeposition of Platinum in Ionic Liquids}

Ionic liquids (ILs), which are molten salts with a melting point below $100{ }^{\circ} \mathrm{C}$, are very attractive electrolytes due to their unique properties: they exhibit in particular very low volatility, good thermal stability, and a wide electrochemical window. This window is usually far larger than $2 \mathrm{~V}$, which makes it possible to perform anodic dissolution and electrodeposition of various metals with a limited ionic liquid degradation $[8,23,24]$. ILs appear promising for the recovery of hardly reducible metals $[9,25,26]$, or noble metals of troublesome oxidation [27-30]. Moreover, ILs composed of coordinating anions (such as $\mathrm{Cl}^{-}, \mathrm{Br}^{-}, \mathrm{SCN}^{-}, \mathrm{N}(\mathrm{CN})_{2}{ }^{-} \ldots$ ) are particularly interesting for leaching purposes, since the reachable concentration of the ligand can be as high as $10 \mathrm{M}$.

\subsection{Experimental Section}

\subsubsection{Chemicals}

1-butyl-3-methyl imidazolium chloride (BMIM Cl) (99\%) and 1-butyl-3-methyl trifluoromethanesulfonate (BMIM OTf) $(98 \%)$ were purchased from Iolitec ${ }^{\circledR}$. Silver trifluoromethanesulfonate (Ag OTf) was purchased from ACROS ${ }^{\circledR}$. 1-butyl-3-methyl imidazolium bromide (BMIM Br) was prepared according to the procedure described in [31]. 1-butyl-3-methyl imidazolium bis(trifluoromethylsulfonyl)imide (BMIM TFSI) was also prepared as reported in [32].

\subsubsection{Electrochemical Experiments}

All electrochemical experiments were performed at $100{ }^{\circ} \mathrm{C}$, using a VSP-300 (Biologic ${ }^{\circledR}$, Claix, France) potentiostat controlled with EC-Lab software and a three-electrode cell. The $\mathrm{Ag}^{+\mathrm{I}} / \mathrm{Ag}$ reference electrode was prepared by immersing an Ag wire $\left(\varnothing=1 \mathrm{~mm}\right.$, Alfa Aesar $\left.{ }^{\circledR}\right)$ in a $10 \mathrm{mM}$ AgOTf solution in BMIM OTf placed in a salt bridge (AL120, CTB Choffel). Voltammetric experiments were performed using glassy carbon or platinum disks $(\varnothing=3 \mathrm{~mm}$ and $2 \mathrm{~mm}$, respectively) as working electrodes, and a glassy carbon disk $(\varnothing=3 \mathrm{~mm})$ as a counter electrode. The sweep rate was fixed at $20 \mathrm{mV} \cdot \mathrm{s}^{-1}$. The disk electrodes were polished mechanically using $5 \mu \mathrm{m}$ and $0.3 \mu \mathrm{m}$ abrasive bands (Radiometer Analytical ${ }^{\circledR}$ ) before each electrochemical experiment. Electroleaching experiments were performed in potentiostatic mode using a $1 \mathrm{~cm}^{2}$ platinum plate $\left(99.99 \%\right.$, AMTS $\left.{ }^{\circledR}\right)$ or a sample of used PEMFC electrode as the anode. A glassy carbon plate with a surface equal to $1 \mathrm{~cm}^{2}$ was used as the cathode. The volume of solution used was $8 \mathrm{~mL}$. Unless otherwise stated, the experiments were performed under inert atmosphere, in a MBraun ${ }^{\circledR}$ Labstar MB 10 Compact glove box, with $\mathrm{O}_{2}$ and $\mathrm{H}_{2} \mathrm{O}$ contents below $0.5 \mathrm{ppm}$.

\subsubsection{Determination of Dissolved Platinum Concentration}

The amount of leached platinum was determined by gravimetry and atomic absorption spectrometry (AAS). The platinum plate anode was weighed before and after its electrochemical dissolution, after rinsing with distilled water and acetone. A quantification method specific to ILs was developed in a previous work to determine platinum concentration by AAS [32]. All AAS measurements were conducted using a Varian ${ }^{\circledR}$ AA 240 spectrometer, controlled with the SpectrAA@ software (Agilent Technologies, Santa Clara, CA, USA).

\subsubsection{Leaching of Platinum Nanoparticles from MEAs}

PEMFC electrodes were supplied by LITEN-CEA in Grenoble. The electrode ink was prepared by mixing Vulcan XC-72 Carbon with $47.3 \mathrm{wt}$. \% of platinum and $26 \mathrm{wt}$. \% of Nafion solution in the mixed organic solvent. The ink was then deposited on the gas diffusion layer consisting of a macroporous substrate treated with 5\% PTFE (Polytetrafluoroethylene) and a microporous layer. The average platinum amount on the used PEMFC electrodes recovered was determined to be close to $75 \mu \mathrm{g} \cdot \mathrm{cm}^{-2}$. The electrodes were characterized before and after dissolution experiments using a Tescan ${ }^{\circledR}$ Vega 3 SBU 
Easy Probe SEM (Scanning Electron Microscopy) with a Bruker ${ }^{\circledR}$ XFlash Detector $410 \mathrm{M}$ controlled by Espris@ 1.9 Software (Bruker, Billerica, MA, USA) to perform EDX (Energy Dispersive X-ray) analysis.

\subsection{Results and Discussion}

\subsubsection{Electrochemical Leaching and Electrodeposition of Platinum}

We demonstrated previously the feasibility of anodic dissolution of platinum followed by its recovery by electrodeposition at a carbon cathode [32,33], using IL electrolytes at temperatures near $100{ }^{\circ} \mathrm{C}$. The electrolyte was a mixture of two ILs having a common cation, $\mathrm{BMIM}^{+}$, associated with two different anions: $\mathrm{Cl}^{-}$and $\mathrm{TFSI}^{-}$. BMIM Cl was chosen due to the complexing property of chloride anions for platinum. However, whereas a high chloride concentration favors the leaching of platinum, it inhibits the metal electrodeposition, which means that $\mathrm{BMIM} \mathrm{Cl}$ cannot be used alone here. In order to reduce the complexing ability of the electrolyte and allow occurrence of Pt electrodeposition, BMIM Cl was used as a solute with another IL-BMIM TFSI—acting as the solvent, since TFSI ${ }^{-}$anion is known to be a low coordinating species. Moreover, the use of such mixed ILs instead of pure BMIM $\mathrm{Cl}$ exhibits further advantages: the mixture is liquid at room temperature, far less viscous than pure ILs at the temperature of interest, and far less hygroscopic. The optimum electrolyte composition was determined for both electrochemical leaching and the electrodeposition of platinum using a single cell process operated in potentiostatic mode.

Further works were dedicated to a deeper understanding of the electrochemical reactions involved in the IL melt. More specifically, the influence of applied potential on the speciation of platinum and on the efficiency of the leaching step was studied in terms of rate and faradaic yield.

Figure 5 presents the linear voltammetric curves obtained using a platinum disk as a working electrode in BMIM TFSI or BMIM Cl alone, and in the mixed IL, whose composition was found to be optimal for Pt recovery.

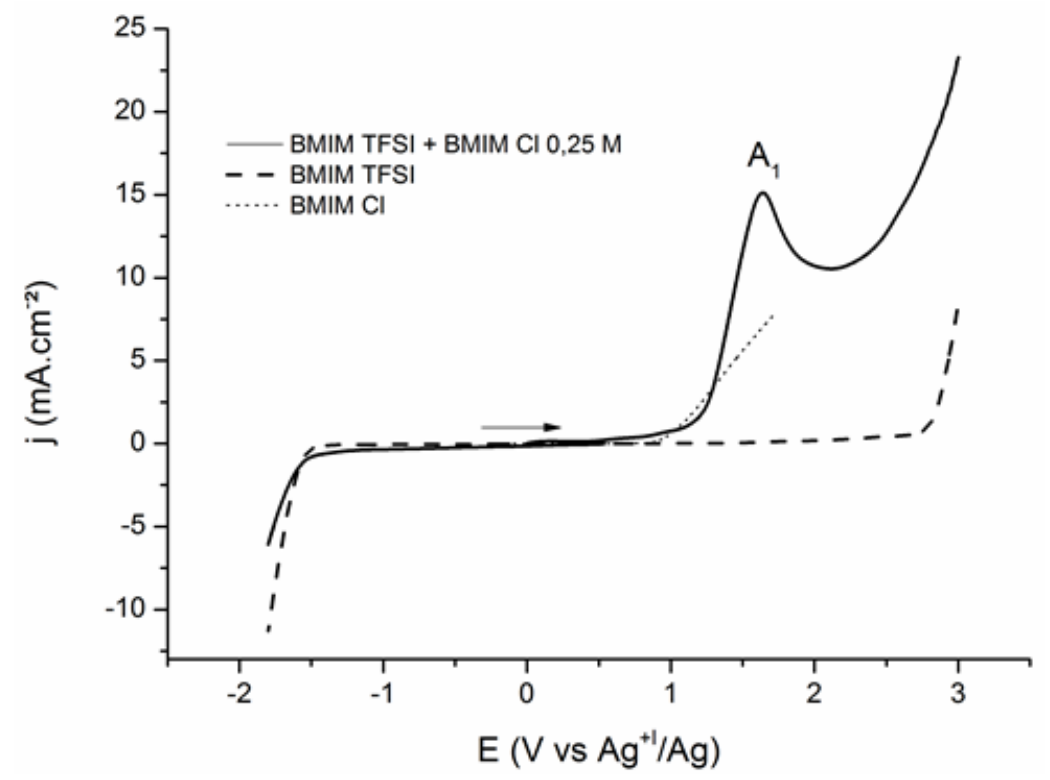

Figure 5. Linear sweep voltammetry on a Pt electrode in various ionic liquid media under inert atmosphere at $100{ }^{\circ} \mathrm{C}$, sweep rate $=20 \mathrm{mV} \cdot \mathrm{s}^{-1}$.

The cathodic stability was identical for the three electrolytes, and limited by the reduction of the $\mathrm{BMIM}^{+}$cation [34] at $-1.5 \mathrm{~V}$ vs. $\mathrm{Ag}^{+\mathrm{I}} / \mathrm{Ag}$. We have previously demonstrated that $\mathrm{Pt}$ cannot be 
oxidized in BMIM TFSI [32]. The oxidation signal observed at $2.8 \mathrm{~V} \mathrm{vs.} \mathrm{Ag}^{+\mathrm{I}} / \mathrm{Ag}$ in BMIM TFSI and in the IL mixture corresponds then to the oxidation of the TFSI ${ }^{-}$anion [34] (7):

$$
\mathrm{N}\left(\mathrm{SO}_{2} \mathrm{CF}_{3}\right)_{2}^{-} \rightarrow \cdot \mathrm{N}\left(\mathrm{SO}_{2} \mathrm{CF}_{3}\right)_{2}+\mathrm{e}^{-}
$$

It has been previously shown that the anodic signal observed in $\mathrm{BMIM} \mathrm{Cl}$ for potential values was higher than $1 \mathrm{~V}$ vs. $\mathrm{Ag}^{+\mathrm{I}} / \mathrm{Ag}$, and the oxidation peak $\mathrm{A}_{1}$ recorded in $0.25 \mathrm{M} \mathrm{BMIM} \mathrm{Cl}$ in BMIM TFSI corresponded to both of the two following oxidation reactions $(8)[35,36]$ and $(9)$, whose occurrence cannot be distinguished from each other in the voltammograms:

$$
\begin{gathered}
3 \mathrm{Cl}^{-} \rightarrow \mathrm{Cl}_{3}^{-}+2 \mathrm{e}^{-} \\
\mathrm{Pt}+\mathrm{xCl}^{-} \rightarrow \mathrm{PtCl}_{x}^{y-x}+\mathrm{ye}^{-}
\end{gathered}
$$

The oxidation of chloride ions must be of little significance for high leaching faradaic yields, and also to avoid appreciable electrolyte degradation.

The speciation of platinum and the efficiency of the leaching step were studied depending on the electrode potential in the range $1.15-2.1 \mathrm{~V}$ vs. $\mathrm{Ag}^{+\mathrm{I}} / \mathrm{Ag}$. Quantitative analysis of platinum content in the electrolyte after leaching was performed by atomic absorption spectrometry (AAS), using analytical procedures specific to ILs media developed previously [32]. Speciation of dissolved platinum was determined by electroanalytical techniques.

Figure 6 compares a voltammogram obtained in the medium after potentiostatic leaching at $E=1.4 \mathrm{~V}$ vs. $\mathrm{Ag}^{+\mathrm{I}} / \mathrm{Ag}$, to that recorded in the same IL mixture containing $15 \mathrm{mM} \mathrm{PtCl}_{4}$ : the two voltammograms were similar to whatever potential value was applied for leaching in the above range. Two reduction signals were seen on the i-E curves: peak $C_{1}$ at $-0.1 \mathrm{~V}$ and peak $\mathrm{C}_{2}$ near $-1.3 \mathrm{~V}$ vs. $\mathrm{Ag}^{+\mathrm{I}} / \mathrm{Ag}$. No platinum deposit was obtained by applying a constant potential corresponding to $\mathrm{C}_{1}$, this signal was therefore attributed to the reduction of $\mathrm{Pt}^{+I V}$ to $\mathrm{Pt}^{+I I}$. On the contrary, pure platinum could be deposited at $-1.3 \mathrm{~V} \mathrm{vs}$. $\mathrm{Ag}^{+\mathrm{I}} / \mathrm{Ag}$, which means that $\mathrm{C}_{2}$ corresponds to the reduction of $\mathrm{Pt}^{+\mathrm{II}}$ to $\mathrm{Pt}^{0}$. It can then be concluded that platinum is leached in the form of $\mathrm{Pt}^{+I V}$ beyond $1 \mathrm{~V}$ vs. $\mathrm{Ag}^{+\mathrm{I}} / \mathrm{Ag}$.

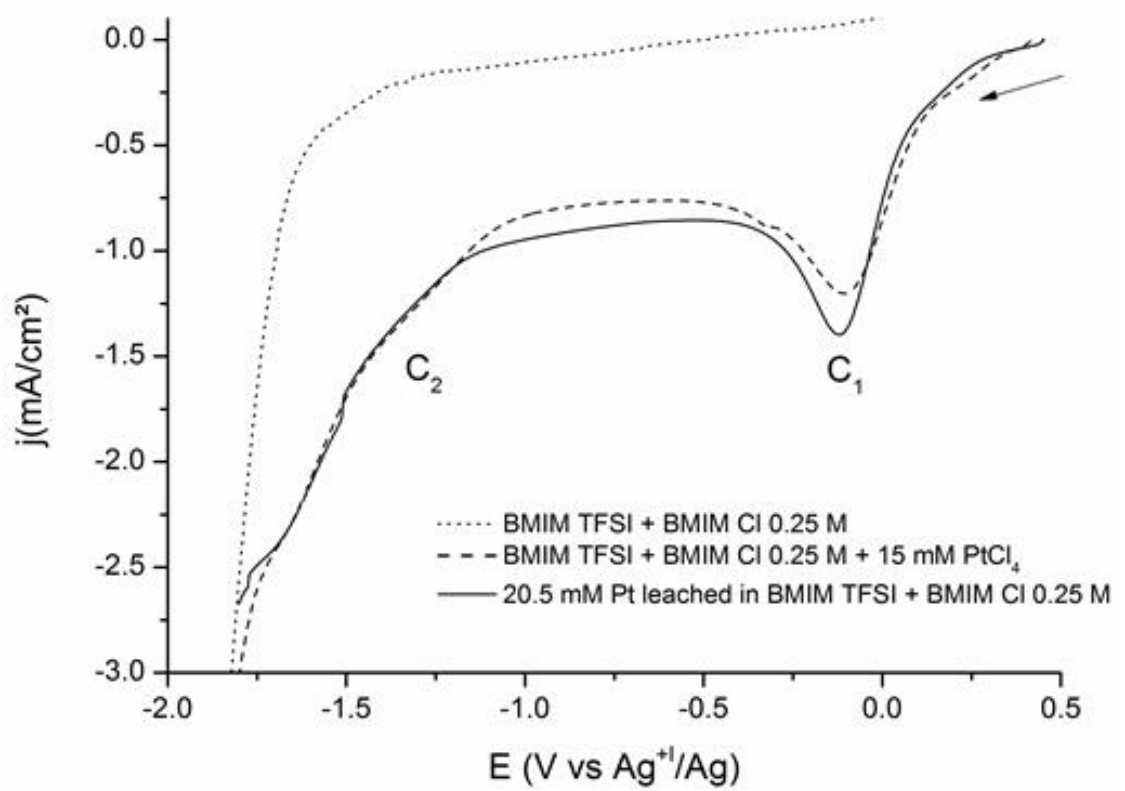

Figure 6. Linear sweep voltammetry performed on a glassy carbon electrode in IL melts under inert atmosphere, $\mathrm{T}^{\circ}=100^{\circ} \mathrm{C}$, sweep rate $=20 \mathrm{mV} \cdot \mathrm{s}^{-1}$. 
According to the literature $[28,37,38], \mathrm{Pt}^{+\mathrm{IV}}$ should be dissolved as a chloride complex. This hypothesis was confirmed by amperometric titration of free chloride ions before and after platinum leaching. It was found that six chloride ions are consumed from the leaching of one $\mathrm{Pt}$ atom, which indicates that leached $\mathrm{Pt}$ in the IL mixture was in the form of a $\mathrm{PtCl}_{6}{ }^{2-}$ complex, as is usually observed in aqueous media.

Chronoamperometric tests of $\mathrm{Pt}$ electroleaching were carried out with $1 \mathrm{~cm}^{2} \mathrm{Pt}$ anode, with a glassy carbon cathode of comparable area. Runs were conducted for a given charge pass, controlling the anode potential. Figure 7 clearly shows that the anode potential had a strong influence on platinum leaching, for both the leaching rate-deduced from the current density-and the faradaic yield. The higher the applied potential, the lower the leaching rate and the faradaic yield: this means that chloride oxidation is favored at higher potential values. Faradaic yield up to $100 \%$ can be reached at "low" applied potential, i.e., below $1.3 \mathrm{~V}$ vs. $\mathrm{Ag}^{+\mathrm{I}} / \mathrm{Ag}$, which means the electrolyte degradation by chloride ions oxidation is very little significant in this domain. The corresponding leaching rate is in the order of $3.3 \mathrm{mg} \cdot \mathrm{h}^{-1} \cdot \mathrm{cm}^{-2}$, which is comparable to the rate obtained in aqua regia solution reported at $4 \mathrm{mg} \cdot \mathrm{h}^{-1} \cdot \mathrm{cm}^{-2}$ in [25]. Taking into account the molecular weight of $\mathrm{Pt}$ and the leaching involving four electrons, this corresponded to a current density of a few $\mathrm{mA} \cdot \mathrm{cm}^{-2}$.

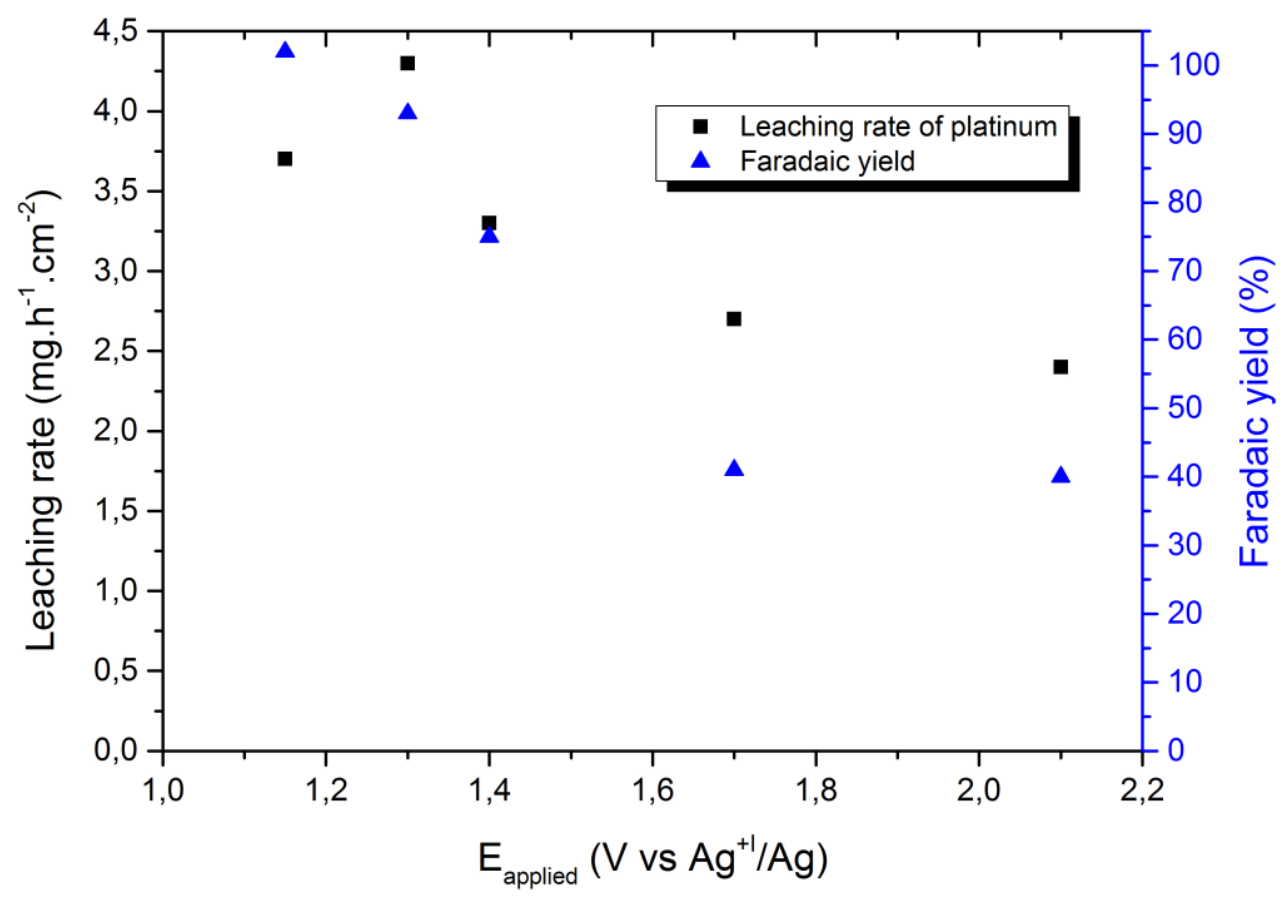

Figure 7. Influence of the applied potential on the leaching rate of platinum and corresponding faradaic yield in runs conducted at $\mathrm{Q}=55 \mathrm{C} \cdot \mathrm{cm}^{-2}$.

Electrodeposition of Pt was then performed in Pt-containing IL mixture, with a $1 \mathrm{~cm}^{2}$ glassy carbon cathode. The cathode potential was controlled in chronoamperometric runs in a range corresponding to the reduction of $\mathrm{Pt}^{+\mathrm{II}}$ to $\mathrm{Pt}^{0}$, using a Pt plate as an anode. This latter was electrochemically leached during the electrodeposition of $\mathrm{Pt}$ at the cathode. It was preferential to add Pt salts at $7.5 \mathrm{mM}$ to allow the occurrence of cathodic reactions in the first minutes of the runs. Deposition of Pt on the cathode was observed to be effective with a cathode potential at $-1.3 \mathrm{~V}$ vs. $\mathrm{Ag}^{+\mathrm{I}} / \mathrm{Ag}$ in the $10 \mathrm{~h}$-long test. The anode potential was stable and equal to $0.91 \mathrm{~V} v s$. $\mathrm{Ag}^{+\mathrm{I}} / \mathrm{Ag}$, a potential value that corresponds to maximum faradaic yield conditions.

Platinum recovery from conducting waste by electroleaching and electrochemical deposition (E/E) in a single cell can then be considered by controlling the cathode potential, without degradation of the electrolyte. 


\subsubsection{Application to the Recycling of Platinum Contained in PEMFC}

This experimental procedure was applied to the recovery of Pt used as catalyst in PEMFC. PEMFC electrodes are carbon-based substrates on which Pt nanoparticles are deposited. A sample of PEMFC electrode with an area of $1 \mathrm{~cm}^{2}$ was placed as an anode, and the cathode was a glassy carbon plate. Because of the very small amount of Pt—nearly $75 \mu \mathrm{g} \cdot \mathrm{cm}^{-2}$ in the used PEMFC electrode-the IL electrolyte was enriched in Pt prior PEMFC electrode treatment by electrochemical leaching of a platinum plate: as expected by the charge passed, the concentration of $\mathrm{Pt}(\mathrm{IV})$ ions produced was measured by AAS at $7.5 \mathrm{mM}$. The combined electroleaching/electrodeposition test was conducted for $10 \mathrm{~h}$.

The SEM aspect of the fuel cell electrode before (a) and after (b) treatment is shown in Figure 8, on the left side. The black part of the SEM image (a) corresponds to the carbon substrate whereas grey areas are for platinum nanoparticles deposited on the electrode. All the platinum nanoparticles of the PEMFC electrode were leached during the $10 \mathrm{~h}$ run (b) —as confirmed by EDX measurements-whereas pure platinum was deposited at the cathode (c). The Pt concentration in the IL bath was not visibly changed by the run.

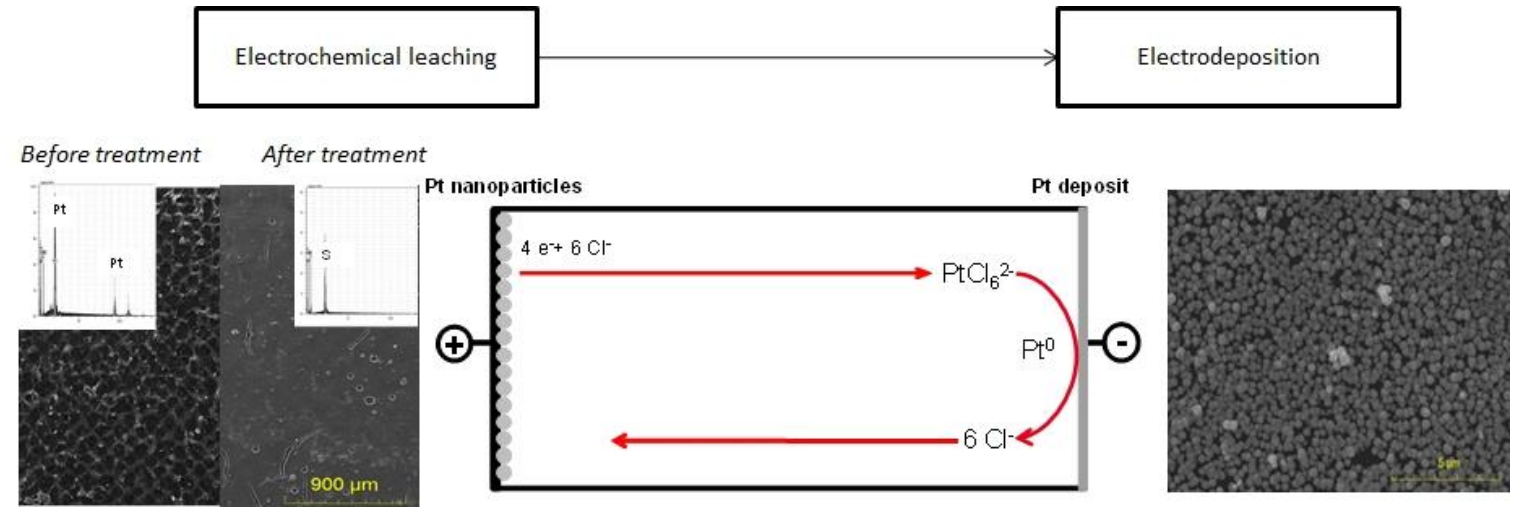

Figure 8. Electrochemical recovery of platinum used in PEMFC electrodes in a 1-butyl-3-methyl imidazolium bis (trifluoromethyl) sulfonyl imide (BMIM TFSI) + BMIM Cl melt containing $7.5 \mathrm{mM}$ of leached Pt under inert and ambient atmosphere.

Coupling of electroleaching to electrodeposition of Pt in IL media has been shown to be a promising route for the recovery of Pt from spent PEMFC. To date, the Pt catalyst represents around $45 \%$ of the total cost of a PEMFC so Pt recycling could be a promising route to reduce the production costs. The current, conventional process for Pt recovery from spent catalysts is very complex, involving several steps, some of them requiring organic solvents or strong acidic solutions e.g., aqua regia.

Further works will consist in the study of experimental parameters that influence the electrodeposition faradaic yield and the morphology of the platinum deposit (applied potential/current density, Pt initial concentration of the electrolyte, nature of the substrate, etc.). The global process parameters can then be optimized for the sake of high recovery yield at an acceptable rate, together with a as long a lifetime of the electrolyte as possible.

This work demonstrates once more that ILs are suitable media for the recovery of precious metals. More specifically, IL melts are promising, since physical and chemical properties of the electrolyte can be tuned to the nature of the metals to be recovered, with a high selectivity even from waste containing numerous other elements.

\section{Conclusions}

Coupling direct or assisted electroleaching to electrodeposition (E/E) in the same cell is an innovative technology classified as a hydrometallurgical hybrid process. This method allows 
the two key steps of the hydrometallurgical processes to be performed in the same reactor, as shown in several worked examples. E/E could be successfully applied to different kinds of waste: electrode materials from end-of-life spent batteries and accumulators $\left(\mathrm{Zn} / \mathrm{MnO}_{2}, \mathrm{Ni} / \mathrm{Cd}\right)$, Waelz oxide, and more recently, MEAs issued from used PEM fuel cells. Whatever the anolyte used-aqueous or ILs-leaching can be performed in soft conditions, avoiding the use of concentrated acids. In ILs, precious metals can be oxidized without hazardous ligands such as cyanide ions. Regarding leaching selectivity, in the examples shown with aqueous solutions, leaching relies on electrogenerated protons, and high selectivity would not be obtained in all conditions; in contrast, in ILs with direct electrochemical leaching, applying the suitable anode potential for the targeted element results in high dissolution selectivity. In aqueous media, selective electrodeposition of the targeted metal is feasible, even with complex catholytes, as shown with the $\left(\mathrm{Cd}^{2+}, \mathrm{Co}^{2+}, \mathrm{Ni}^{2+}\right)$ catholyte obtained from the black mass issued from spent $\mathrm{Ni} / \mathrm{Cd}$ accumulators. Use of ILs as an electrolyte allows recovery at the cathode of metals whose reduction cannot be envisaged in aqueous media.

For coupled electro-assisted leaching/electrodeposition in aqueous media, existing published data and developed chemical engineering methodologies are often sufficient to consider in the short term for a pilot process to be designed. In contrast, E/E in ILs is a very new concept for which additional investigations are required for possible development of this promising route; in particular on (i) improved knowledge in metal speciation in ILs with suitable analytic methods; (ii) better durability of the ILs used in a process with nearly perfect selectivity of electrode processes, and (iii) enhancement of current densities for higher production rates by improvement of IL properties and cell designs.

Author Contributions: M.B.: E/E in ILs; C.H.: Ni-Cd E/E treatment in aqueous medium; J.C.: Ni-Cd E/E treatment in aqueous medium; N.L., F.L.: co-supervisors of aqueous medium studies; S.L., E.B.: co-supervisors of ILs studies; E.M.: scientific leader of hydrometallurgical processes research theme and co-supervisor of M.B. and C.H. PhD thesis.

Funding: Part of the work presented here has been completed within the CEATech program with funding from Region Lorraine. Most facilities used have been co-funded within the Contract "Sustainable Chemistry and Processes" (CPER) between French government and Region Lorraine, with contribution of European Union (FEDER).

Conflicts of Interest: The authors declare no conflicts of interest.

\section{References}

1. Venkateswaran, K.V.; Ramachandran, P. Electroleaching of sulfides-A review. Bull. Electrochem. 1985, 1, 147-155.

2. Kirk, D.W.; Gehring, R.; Graydon, W.F. Electrochemical leaching of a silver arsenopyrite ore. Hydrometallurgy 1987, 17, 155-166. [CrossRef]

3. Elsherief, A.E. A study of the electroleaching of manganese ore. Hydrometallurgy 2000, 55, 311-326. [CrossRef]

4. Kumari, A.; Natarajan, K.A. Electroleaching of polymetallic ocean nodules to recover copper, nickel and cobalt. Miner. Eng. 2001, 14, 877-886. [CrossRef]

5. Pozzo, R.L.; Malicsi, A.S.; Iwasaki, I. Removal of lead from printed-circuit board scrap by an electrodissolution-delamination method. Resour. Conserv. Recycl. 1991, 5, 21-34. [CrossRef]

6. Soare, V.; Dumitrescu, D.; Burada, M.; Constantin, I.; Soare, V.; Capota, P.; Popescu, A.M.; Constantin, V. Recovery of Metals from Waste Electrical and Electronic Equipment (WEEE) by Anodic Dissolution. REV Chim-Buchar. 2016, 67, 920-924.

7. Kim, E.Y.; Kim, M.S.; Lee, J.C.; Pandey, B.D. Selective recovery of gold from waste mobile phone PCBs by hydrometallurgical process. J. Hazard. Mater. 2011, 198, 206-215. [CrossRef] [PubMed]

8. Abbott, A.P.; Frisch, G. Ionometallurgy: Processing of Metals Using Ionic Liquids, in Element Recovery and Sustainability; Andrew, J.H., Ed.; The Royal Society of Chemistry: Cambridge, UK, 2013; pp. 59-79.

9. Abbott, A.P.; McKenzie, K.J. Application of ionic liquids to the electrodeposition of metals. Phys. Chem. Chem. Phys. 2006, 8, 4265-4279. [CrossRef] [PubMed] 
10. Page, P.W.; Brandon, N.P.; Mahmood, M.N.; Fogarty, P.O. One-step recovery of nickel by an electrohydrometallurgical process. J. Appl. Electrochem. 1992, 22, 779-786. [CrossRef]

11. Guillaume, P. Recherche d'un Protocole de Traitement de Solides Zincifères Par Voie Électrochimique: Couplage Électrolixiviation/Électrodéposition Dans Une Cellule Unitaire. Ph.D. Thesis, University of Metz, Metz, France, 2008.

12. Guimaraes, Y.F.; Santos, I.D.; Dutra, A.J.B. Direct recovery of copper from printed circuit boards (PCBs) powder concentrate by a simultaneous electroleaching-electrodeposition process. Hydrometallurgy 2014, 149, 63-70. [CrossRef]

13. Hazotte, C. Traitement de la Matière active D'accumulateurs Ni-Cd en fin de vie par Couplage Electrolixiviation/Electrodéposition. Ph.D. Thesis, University of Lorraine, Lorraine, France, 2014.

14. Balva, M. Etude du Recyclage en Milieu Liquide Ionique de Platinoïdes Immobilisés sur Support Solide Pour une Valorisation Dans la Filière Pile à Combustible. Ph.D. Thesis, University of Lorraine, Lorraine, France, 2017.

15. Urzúa-Abarca, D.A.; Fuentes-Aceitunoa, J.C.; Uribe-Salas, A.; Lee, J.C. An electrochemical study of silver recovery in thiosulfate solutions. A window towards the development of a simultaneous electroleaching-electrodeposition process. Hydrometallurgy 2018, 176, 104-117. [CrossRef]

16. Guillaume, P.; Leclerc, N.; Lapicque, F.; Boulanger, C. Electroleaching and electrodeposition of zinc in a single-cell process for the treatment of solid waste. J. Hazard. Mater. 2008, 152, 85-92. [CrossRef] [PubMed]

17. Hazotte, C.; Leclerc, N.; Meux, E.; Lapicque, F. Direct recovery of cadmium and nickel from Ni-Cd spent batteries by electroassisted leaching and electrodeposition in a single-cell process. Hydrometallurgy 2016, 162, 94-103. [CrossRef]

18. Hazotte, C.; Leclerc, N.; Diliberto, S.; Meux, E.; Lapicque, F. End-of-life nickel-cadmium accumulators: Characterization of electrode materials and industrial Black Mass. Environ. Technol. 2015, 36, 796-805. [CrossRef] [PubMed]

19. Comel, J. Optimisation du Traitement D'accumulateurs Ni/Cd par Couplage Électrolixiviation/Électrodéposition; Internal Report; Institut Jean Lamour, Université de Lorraine: Metz, France, 2017.

20. Hazotte, C.; Meux, E.; Leclerc, N.; Lapicque, F. Electroassisted leaching of black mass solids from Ni-Cd batteries for metal recovery: Investigation of transport and transfer phenomena coupled to reactions. Chem. Eng. Process. 2015, 96, 83-93. [CrossRef]

21. Guillaume, P.; Leclerc, N.; Boulanger, C.; Lecuire, J.M.; Lapicque, F. Investigation of optimal conditions for zinc electrowinning from aqueous sulfuric acid electrolytes. J. Appl. Electrochem. 2007, 37, 1237-1243. [CrossRef]

22. Devilliers, D.; Tillemant, O.; Vogler, M. Mise au point sur l'activité et les réalités électrochimiques en France et au plan international. L'actualité Chim. 1992, 1, 5-34.

23. Silvester, D.S.; Rogers, E.I.; Compton, R.G.; Mckenzie, K.J.; Ryder, K.S.; Endres, F.; Macfarlane, D.; Abbott, A.P. Technical Aspects. In Electrodeposition from Ionic Liquids; Wiley-VCH Verlag GmbH \& Co. KGaA: Weinheim, Germany, 2008; pp. 287-351.

24. Ohno, H. Physical Properties of Ionic Liquids for Electrochemical Applications. In Electrodeposition from Ionic Liquids; Wiley-VCH Verlag GmbH \& Co. KGaA: Weinheim, Germany, 2008; pp. 47-82.

25. Li, Q.; Jiang, J.; Li, G.; Zhao, W.; Zhao, X.; Mu, T. The electrochemical stability of ionic liquids and deep eutectic solvents. Sci. China Chem. 2016, 59, 571-577. [CrossRef]

26. Endres, F. Ionic liquids: Solvents for the electrodeposition of metals and semiconductors. ChemPhysChem 2002, 3, 144-154. [CrossRef]

27. Billy, E. Application des Liquides Ioniques à la Valorisation des Métaux Précieux Par Une vOie de Chimie Verte. Ph.D. Thesis, University of Grenoble, Saint-Martin-d'Hères, France, 2012.

28. Deferm, C.; Hulsegge, J.; Moller, C.; Thijs, B. Electrochemical dissolution of metallic platinum in ionic liquids. J. Appl. Electrochem. 2013, 43, 789-796. [CrossRef]

29. Barrosse-Antle, L.E.; Bond, A.M.; Compton, R.G.; O’Mahony, A.M.; Rogers, E.I.; Silvester, D.S. Voltammetry in Room Temperature Ionic Liquids: Comparisons and Contrasts with Conventional Electrochemical Solvents. Chem. Asian J. 2010, 5, 202-230. [CrossRef] [PubMed]

30. Abbott, A.P.; Frisch, G.; Hartley, J.; Wrya, O.; Karima, W.O.; Rydera, K.S. Anodic dissolution of metals in ionic liquids. Prog. Nat. Sci. Mater. Int. 2015, 25, 595-602. [CrossRef] 
31. Wu, J.; Zhu, X.; Li, H.N.; Su, L.; Yang, K.; Cheng, X.R.; Yang, G.Q.; Liu, J. Combined Raman Scattering and X-ray Diffraction Study of Phase Transition of the Ionic Liquid BMIM TFSI Under High Pressure. J. Solut. Chem. 2015, 44, 2106-2116. [CrossRef]

32. Balva, M.; Legeai, S.; Leclerc, N.; Meux, E.; Billy, E. Environmentally friendly recycling of fuel cell's membrane electrode assembly using ionic liquids. ChemSusChem 2017, 10, 2922-2935. [CrossRef] [PubMed]

33. Balva, M.; Legeai, S.; Leclerc, N.; Billy, E.; Meux, E. Procédé de Récupération de Platine, Par Voie Électrochimique, à Partir d'un Matériau Dans Lequel il est Contenu. Patent N EN: 16 56293, 1 July 2016.

34. De Vos, N.; Maton, C.; Stevens, C.V. Electrochemical Stability of Ionic Liquids: General Influences and Degradation Mechanisms. Chemelectrochem 2014, 1, 1258-1270. [CrossRef]

35. Aldous, L.; Silvester, D.S.; Villagran, C.; Pitner, W.R.; Compton, R.G.; Lagunas, C.; Hardacre, C. Electrochemical studies of gold and chloride in ionic liquids. New J. Chem. 2006, 30, 1576-1583. [CrossRef]

36. Zhang, Q.B.; Hua, Y.X.; Wang, R. Anodic oxidation of chloride ions in 1-butyl-3-methyl-limidazolium tetrafluoroborate ionic liquid. Electrochim. Acta 2013, 105, 419-423. [CrossRef]

37. Katayama, Y.; Endo, T.; Miura, T.; Toshima, K. Electrode Reactions of Platinum Bromide Complexes in an Amide-Type Ionic Liquid. J. Electrochem. Soc. 2013, 160, D423-D427. [CrossRef]

38. Huang, J.F.; Chen, H.Y. Heat-Assisted Electrodissolution of Platinum in an Ionic Liquid. Angew. Chem. Int. Edit. 2012, 51, 1684-1688. [CrossRef] [PubMed]

(C) 2018 by the authors. Licensee MDPI, Basel, Switzerland. This article is an open access article distributed under the terms and conditions of the Creative Commons Attribution (CC BY) license (http:/ / creativecommons.org/licenses/by/4.0/). 